\title{
Interlinking of Peri-Urban Lakes Based on Water Quality and Yield Using GIS for Efficient Water Management in Chennai, India
}

Pachaivannan Partheeban ( $\sim$ parthi011@yahoo.co.in )

Chennai Institute of Technology https://orcid.org/0000-0003-4345-0741

Baskaran Anuradha

Chennai Institute of Technology

Elangovan Arunbabu

Anna University Chennai

Krishnan Somasundaram

Chennai Institute of Technology

Chandarasekaran Hariharasudhan

Chennai Institute of Technology

Research

Keywords: Water yield, Water Conservation, runoff, groundwater, Linking lakes

Posted Date: July 9th, 2021

DOl: https://doi.org/10.21203/rs.3.rs-664437/v1

License: (9) This work is licensed under a Creative Commons Attribution 4.0 International License. Read Full License 


\section{Abstract}

This paper aims at providing a solution for augmenting the runoff water from major lakes of Chennai and Thiruvallur district of Tamilnadu. Hence an attempt was made to save surplus water from Puzhal, Ayanambakkam, Koratur, Ambattur, and Retteri lakes have been proposed. To interlink Puzhal lake with Koratur lake alignment is considered as it passes through the road network, excluding built-up areas. Water quality analysis was also done with a minimum of three samples that were collected from each lake. Samples were tested for $\mathrm{pH}$, Total dissolved solids, Total suspended Solids, and Chemical oxygen demand. The linking of the lakes is proposed based on the water quality assessment of each lake. This study suggests an efficient/optimal route or canal for interlinking lakes in a GIS environment. The elevation differences, slope and dimensions of the canal, and the possible best location to link the lakes/tanks were obtained through the spatial data in the GIS. This helps in an effective and optimized management of the water supply for Chennai city.

\section{Introduction}

Water is required in all walks of life. Global natural changes and the need for various utilization of expanding populace make water the board of troublesome assignment, particularly in creating nations like India with detonating populace and powerless economy. All the more explicitly, developing interests across serious areas, expanding dry seasons, declining water quality, especially of groundwater, unabated flooding, between-the-states waterway debates, developing money related crunch, lacking institutional changes and implementation are portions of the pivotal issues looked into by the nation's water division. Extreme water deficiencies have just prompted a developing number of contentions between clients (horticulture, industry, residential), intra-state, and between-state. With the expanding interest for water from different areas like horticulture and family unit businesses, a relevant need emerges from the administration part just as it is from the private segment on water assets administration. Objectives of this research paper are to save water which is being wasted as runoff from Tiruvallur Lake, to protect Tiruvallur district lakes from encroachments, to increase groundwater recharge by storing water in lakes, to make water available during summer, to satisfy the water demand of newly extended boundary of Chennai, and to Study the water quality on the selected lakes in order, linking lakes having similar water qualities or type of treatment required before interlinking of lakes.

\section{Review Of Literature}

In southern parts of India, irrigation tanks are prevailing for decades together ([1], [2], [3], (Chapman, 1996)). One of the most unmistakable action centers in Indian urban communities is the up degree of the urban seepage framework and best urban stormwater management practices. A major portion of the investment was on constructing stormwater drains and adopting low-impact development concepts in towns and cities to prevent flooding during heavy storms. Stormwater drains are required to feed all the surface runoff accumulated into the nearest surface water source, such as a lake or river, in the town or area [5]. Lakes in urban and peri-urban regions are a critical interface between arrangement and nature, 
requiring earth-responsive strategies, identifying issues such as flooding, water pollution, and water quality with their complexity in plan and engineering. The standard assessment of Ahmedabad's six interlinked urban pools has been completed to determine pollution levels in the lakes. It has been discovered that the contaminations stacking from untreated tempest water are released using seepage from urban catchments [6, 7]. EPA-SWMM (Storm Water Management Model) shows the stormwater waste and the lakes to identify the wellsprings with pollution loadings. The situation was exacerbated when the inflows arrive at the downstream outflow, where the aggregated significant poison loads are released in the water. It was inferred from the analysis that research undertakings such as linking lakes influence the quality of water on lakes and disrupt the parity of the lake's biological structure and contaminate the water.

Interlinking of lakes and ponds leads to diluting the pollutants and increasing the water quality [8]. Just like interlinking rivers, the same procedure is also possible for small water storage structures [9]. A catchment is the territory of the land that channels water into a water body. A catchment is arranged into a smaller scale watershed, milli-watershed, a typical edge isolates sub watershed, watersheds, subcatchments, catchments, bowl, district, and a catchment. Catchment yield relies on the precipitation, waste thickness, geology, soil type, land use, and so forth while the yield of a catchment is the complete amount of water that can be normal in a stream in a given timeframe, for example, month to month, yearly, and so forth [3]. Lakes have various uses and are significant regions of human defray and occupation [10]. The increase of impermeable surfaces in urban areas and increased water movement in lakes has caused polluting declines in urban lakes [11].

[12] studied the various chemicals present in the Sambhar Soda Lake water situated in Rajasthan. The results showed that maximum pH is 9.5 , sodium $(9930 \mathrm{mg} / \mathrm{L})$, chloride $(7356 \mathrm{mg} / \mathrm{L})$, bicarbonates $(6080$ $\mathrm{mg} / \mathrm{L})$, sulfate $(9152 \mathrm{mg} / \mathrm{L}$. This study was on a saltwater lake and concluded that they required continuous monitoring. [13] examined the Genotoxicity of water pollution at three sites of the Lake Sevan Basin. They discovered that there was a significant positive correlation between the parameter of the Olive tail moment in crayfish and the content of $\mathrm{Al}, \mathrm{Fe}, \mathrm{Cu}$, and Mo. [14] investigated the water content of 87 groundwater samples from Rameswaram Island, including $\mathrm{pH}$, electrical conductivity (EC), total dissolved solids (TDS), salinity, total alkalinity (TA), calcium hardness $(\mathrm{CH})$, magnesium hardness, total hardness $(\mathrm{TH})$, chloride, and fluoride. Statistical instruments are used to analyze their findings. They concluded that a proper management strategy to provide potable water was needed. [15] investigated the groundwater condition in Karayanchavadi, a suburb of Chennai near the Bay of Bengal. 30 samples of groundwater were obtained and tested for $\mathrm{pH}, \mathrm{EC}$, TDS, TA, TH, Ca2+, Mg2+, $\mathrm{Na}+, \mathrm{K}+, \mathrm{Cl}-, \mathrm{SO} 4-2$, NO3 and it was discovered that the $\mathrm{pHs}$ of all the wells were acidic to mildly alkaline.

[16] conducted the water quality analysis of Purur double lake, Chennai lakes. Five different samples were collected from various locations and results of various chemical contents were presented and discussed. The Water Quality Status of Three Vulnerable Freshwater Lakes in Chennai was investigated [17]. 
Lakes are natural collectors of water drainage from pervious and impervious surfaces. Direct and indirect discharge from residential and industrial areas in urban areas, rendering them vulnerable receivers and resistant to eutrophication, is one of the most frequent and severe problems they face. The use of lake waters is impacted by the loss of lake water content due to harmful physical interference. Anthropogenic practices and municipal catchments, which drain wastewater to urban water bodies, are the main pollutants in lakes, especially in urban environments, where a range of wastes can produce high toxic levels in streams, contaminating lakes directly by surface runoff. In general, lakes are exposed to various toxic substances that can potentially disrupt the lake system's balance [18]. Surface runoff from streets, surface wastes from industrial and business areas are examples of diffuse urban origins. When liquid runoff flows into natural or artificial storm drains, there is diffusion from surface water passing into waste collection sites and combined inputs from various locations. Slums surround the wetlands cause lake waters to contact human excrement due to unregulated waste link dumps.

A study was carried out by [19] for the Lake Naivasha Basin in Kenya's Rift Valley. They considered two water supply problems for horticulture and weather conditions in that lake area for developing a hydroeconomic model. They developed a Multiple Optimization Problems with Equilibrium Constraints (MOPEC) model for economic aspects. [20] conducted a study on entry of microplastic of less than $5 \mathrm{~mm}$ in Redhills lake which is one of the major water supply lakes to Chennai city, Tamilnadu, India. The present study was also carried out on one among the lake considered for interlinking. They examined 32 sediment samples covering the entire lake and the mean concentration of 27 particles per $\mathrm{kg}$.

A model developed for groundwater quality considers both users and non-users but experts in hydrology [21]. Parameters considered for modeling include groundwater quantity, climate change, sociohydrogeology, policymakers, media, and communications experts, mobile technology developers, and social scientists. They concluded that developing a better understanding of the relationship between societies and hydrogeological processes will be the freshwater wealth for future generations. [22] investigated the characteristics of two nearby lakes based on the best usage criterion for optimization and use. They analyzed 20 parameters of these two lakes for 3 months observations and analyzed the water quality index concerning the depth of water in the lakes and they also had an introduction of a Modified Water Quality Index.

The benthic invertebrate composition was altered in many areas of the Great Lakes due to invasions by dreissenid mussels and the round goby, making the use of the benthic invertebrate composition as an indicator of environmental conditions more difficult [23]. Changes in benthos were more closely linked to dreissenid and goby invasions than changes in environmental quality. A study was conducted on water quality analysis modelled for Canada's ice river lake system [24]. The environmental quality of water connecting basins on the upstream side was assessed using their simulation model. Their model's output could lower total ammonia and orthophosphate concentrations throughout the year, especially at Buffalo Pound Lake. The mean absolute error for ammonium ranged from 0.03 to $0.08 \mathrm{NH} 4-\mathrm{N} / \mathrm{L}, 0.5$ to $1.7 \mathrm{mg} / \mathrm{L}$ for oxygen, and 0.04-0.13 NO3-N/L for nitrate. 
Lake systems can be harmed by excessive recreational usage, unregulated lake utilization, and human activity around the lake. Chemical, nutrient, organic, and microbiological concentrations in surface and sediments result from exposure to different causes of pollution. The contaminant load (mass per unit time) distributed in the lake determines the lake concentration, referred to as filling (mass per unit volume or area per unit time). When developing water quality standards and strategies focused on permissible concentrations, it is critical to distinguish between contaminant loads and packing [18]. Pollution in urban lakes is caused by various exogenous and endogenous causes, making it difficult to regulate the level of pollution. The most direct solution is to minimize point source contamination by diverting effluents from agricultural, urban, and domestic sources and controlling solid waste dumped in lakes for recreational purposes. Since pollutant loads still pass-through flood network pipes, identifying contaminated urban catchments is critical for reducing pollutant loads in the storm drainage system. Other techniques include siphoning fresh water from rivers, underwater sources, and irrigation, which may have beneficial consequences if performed selectively, preferably towards the end of the stratification phase [25].

The 'solution by dilution technique, on the other hand, is dependent on the context of the lakes and the source of the siphoned water. The drainage of accumulated sludge along flood water inlets around urban lakes is necessary for the lakes to restore equilibrium.

\section{Methodology}

For the past 20 years, the annual rainfall data of the Chennai district are collected from Public Works Department (PWD) Chennai. The study area map is presented in Fig. 1. The data obtained has been used for the analysis of maximum rainfall, minimum rainfall, and average rainfall. The data are analyzed for consistency and are used for the calculation of the yield of the catchment. Catchment boundaries of the lakes are obtained from soil and land use survey of India site and the boundaries, area of the catchment area is marked based on the key provided. The lakes are selected, so they are close to the reservoir to link easily. Lakes that yield huge runoff during monsoon and lakes that are already connected naturally or artificially are studied. Samples are collected based on central pollution control board norms.

Samples are collected from a minimum of three sides of the lakes and are tested in the laboratory. The tests that are conducted in the laboratory are chemical oxygen demand, total dissolved solids, and pH. Catchment yield is calculated using rainfall data, catchment area, and land use map. Different coefficients are assumed based on the type of land use Runoff is calculated using excess water let out and the capacity of the lakes' series. The surplus water from the series of lakes is diverted to a nearby reservoir, Puzhal Lake. Different alignments have been considered to interlink Puzhal lake and the series of lakes so that when it is empty, the surplus water from these lakes can flow into Puzhal in a gravity flow.

GIS technology is widely used for land resource management and urban planning. In this study, QGIS open-source software is used for linking the lakes in the urban area. GIS is used to find out the suitable canal alignment by considering the shortest path to connect different lakes, the elevation of the lakes, 
water quality from the water sample analysis in the different lakes, and population in and around the lakes.

\section{Result And Analysis}

Criteria behind the selection of tanks are that all the lakes should be located nearer to the reservoir to link easily, they should have a reasonable capacity preferably $<0.15 \mathrm{TMC}$, and the catchment yields a high quantity of water, annually. Table 1 presents the Capacity of each lake, catchment area, and mean depth. Lakes that yield huge runoff during monsoon and lakes that are already connected naturally or artificially are studied.

Ayanambakkam Lake is one of the lakes in the Chennai district located in Ayanambakkam village near Thiruverkadu, which has a water-spread area of over $0.849 \mathrm{sq} . \mathrm{km}$. This lake is also a significant source of water for the metropolitan areas of Chennai city. Earlier it was used for farming, but due to rapid industrialization and growth, the lakes' water quality has deteriorated to a great extent. Ambattur Lake is a rainfed reservoir that reaches its maximum level during the monsoon seasons. In November 2008, incessant monsoon rain flooded the lake, and invasions of the lake's north and south banks were demolished. It also meets the drinking water needs of Chennai city next to lake Poondi and Lake Chembarambakkam. It is one of the lakes in the chain of three water bodies, namely Korattur and Madhavaram, where surplus water is transferred from one to another. It is highly polluted due to domestic and sewage. Retteri lake is apart with flora and fauna and the water quality is quite good compared to other lakes. The size of the lake is greatly reduced due to encroachments. Korattur lake holds a water spread area of over $4.006 \mathrm{sq}$. $\mathrm{km}$. It is one of the largest lakes in the western part of the city and is a chain of three lakes, including Ambattur, Madhavaram where surplus water from one is discharged to another. The water from the lake has been supplied to Chennai residents when there was a shortage in the late 1970s. Due to urbanization, the lake has been polluted to a greater amount, and the lake has shrunk to nearly two-third due to illegal encroachments. Details of the land use in the study area are presented in Table 2. 
Table 1

Capacity of Lakes

\begin{tabular}{|lllll|}
\hline S.No & Name of the lake & Area in Sq. kM & Mean Depth in ft & Capacity in TMC \\
\hline 1 & Puzhal & 18.21 & -15.30 & 3.300 \\
\hline 2 & Ayanampakkam & 0.809 & -3.50 & 0.087 \\
\hline 3 & Ambathur & 2.203 & -3.20 & 0.228 \\
\hline 4 & Koratur & 2.428 & -2.50 & 0.214 \\
\hline 5 & Rettaieri & 1.821 & -2.35 & 0.150 \\
\hline & Total & & & $\mathbf{0 . 6 7 9}$ \\
\hline
\end{tabular}

Table 2

Land use of Study Area (Hectares)

\begin{tabular}{|lllll|}
\hline Description & Aynambakkam & Ambattur & Retteri & Korattur \\
\hline Built up area, urban & 470 & 1758.21 & 1272.47 & 570.41 \\
\hline Built up area, urban & 76.7 & 1.87 & 9.53 & 7.37 \\
\hline Water body & 146.5 & 184 & 142 & 250.92 \\
\hline Agricultural land & 316.8 & 45.92 & 306 & 126.3 \\
\hline
\end{tabular}

The total amount of water that can be predicted in a stream over any period, such as monthly, annually, etc. (Refer Table 3). It is a function of the catchment area, rainfall, type of soil, and land use. The coefficient of runoff varies used on the type of land use it is subjected to:

$Q=C A P$

Where C - Runoff coefficient - given in Table 3 based on land use.

A - Area under the land use in sq. $\mathrm{ft}$;

$P$ - Rainfall in $\mathrm{mm}$ 
Table 3

Runoff Coefficient

\begin{tabular}{|ll|}
\hline Land use & Runoff coefficient \\
\hline Forests & $0.1-0.2$ \\
\hline Plantations & $0.2-0.6$ \\
\hline Agriculture & $0.4-0.7$ \\
\hline Open spaces, grassland & $0.5-0.8$ \\
\hline Built-up & $0.7-0.9$ \\
\hline Rocky areas, water bodies & $0.8-1$ \\
\hline From the rainfall datas average rainfall of Chennai is $1317 \mathrm{~mm}$ ie.
\end{tabular}

From the rainfall data's average rainfall of Chennai is $1317 \mathrm{~mm}$, i.e. $4.32 \mathrm{ft}$ since $(1 \mathrm{~mm}=1 / 304.8 \mathrm{ft})$

\section{Ayambakkam}

$Q=\varepsilon(C A)$

$\mathrm{P}=(0.8 \times 470+0.7 \times 76.7+1 \times 746.5+0.6 \times 316.8)$ hec $X \mathrm{P}$ in $\mathrm{ft}$

$=766.27$ hectares $X \mathrm{Pft}$ since $(1$ hectare $=107639 \mathrm{sq} \mathrm{ft})$

$\mathrm{Q}=766.27 \times 107639 \times \mathrm{P}$

$=82.48 \times 10^{6} \mathrm{sq} f \mathrm{ft} P$ in feet

\section{Ambattur}

$Q=\varepsilon(C A)$

$\mathrm{P}=(0.8 \times 1758.21+0.7 \times 1.87+1 \times 184+0.6 \times 45.92)$ hec $X \mathrm{P}$ in $\mathrm{ft}$

$=1619.429$ hectares $X \mathrm{Pft}$ since $(1$ hectare $=107639 \mathrm{sq} \mathrm{ft})$

$\mathrm{Q}=1619.429 \times 107639 \times \mathrm{P}$

$=174.31 \times 10^{6}$ sq feet $X$ in feet

\section{Koratur}

$Q=\varepsilon(C A) P$

$=(0.8 \times 570.41+0.7 \times 7.37+1 \times 250.92+0.6 \times 126.3)$ hec $X \mathrm{P}$ in $\mathrm{ft}$

$=788.187$ hectares $X P$ ft since $(1$ hectare $=107639 \mathrm{sq} \mathrm{ft})$

$\mathrm{Q}=788.187 \mathrm{X} 107639 \times \mathrm{P}$ 
$=83.76 \times 10^{6}$ sq feet $X P$ in feet

\section{Retteri}

$Q=\varepsilon(C A) P$

$=(0.8 \times 1272.47+0.7 \times 9.53+1 \times 142+0.6 \times 306)$ hec $\times \mathrm{P}$ in $\mathrm{ft}$

$=1350.247$ hectares $X P \mathrm{ft}$ since $(1$ hectare $=107639 \mathrm{sq} \mathrm{ft})$

$Q=1350.247 \times 107639 \times P$

$=145.3 \times 10^{6}$ sq feet $X P$ in feet

Retteri is at downstream direction hence water has to be pumped to divert it there are two cases.

Without considering Retteri $(\mathrm{P}=$ average rainfall) Yield of the catchment

$=\left(82.48 \times 10^{6} \mathrm{sq}\right.$ feet $X \mathrm{P}$ in feet $)+\left(174.31 \times 10^{6}\right.$ sq feet $X \mathrm{P}$ in feet $)+\left(83.76 \times 10^{6}\right.$ sq feet $X \mathrm{P}$ in feet $)$

$=\left[(82.48+174.31+83.76) \times 10^{6}\right]$ in sq ft $X P$ in feet

$=340.55 \times 10^{6}$ in sq ft $X \mathrm{P}$ in feet

From the rain fall data's average rainfall of Chennai $=1317 \mathrm{~mm}=4.32 \mathrm{ft}$ since $(1 \mathrm{~mm}=1 / 304.8 \mathrm{ft})$.

Therefore yield of the catchment $=340.55 \times 106 \times 4.32 \mathrm{cu} . \mathrm{ft}=1.471 \times 109$ cubic feet $=1.471$ (TMC)

The water wasted due to overflowing of lakes= (yield of the catchment - the sum of the capacity of the lakes) The Water wasted as runoff $=1.471-0.529=0.942 \mathrm{TMC} \approx 1 \mathrm{TMC}$

The Water wasted as runoff is equal to $1 \mathrm{TMC}$ which is $30 \%$ of Puzhals maximum storage (3.3 TMC) capacity feet $=485.85 \times 106 \times \mathrm{P}$ in fee $=485.85 \times 106 \times 4.32$ cubic feet $=2.098$ thousand million cubic feet

The Water wasted due to overflowing of lakes = (yield of the catchment -the sum of the capacity of the lakes) The Water wasted as runoff $=2.098-0.679=1.419 \mathrm{TMC} \approx 1.5 \mathrm{TMC}$

The Water wasted as runoff is equal to 1.5 TMC, which is $45 \%$ of Puzhal's storage ( 3.3 TMC) capacity.

\section{Water Quality Analysis}

A minimum of three samples was collected from each lake. Samples were tested for $\mathrm{pH}$, Total dissolved solids, Total suspended Solids, and Chemical oxygen demand and the results are given in Table 4. These results will be considered while planning for the interlinking of these lakes. Further, these parameters are within the permissible limits of WHO standards except TDS for Aynambakkam lake and Korattur lake. Hence a proper remedy is taken before linking of lake's plan and design. 
Table 4

Water Quality of the Lakes

\begin{tabular}{|lllllll|}
\hline Parameters & $\begin{array}{l}\text { Permissible limits WHO } \\
\text { \& CPCB }\end{array}$ & Puzhal & Aynambakkam & Ambattur & Korattur & Retteri \\
\hline pH & $6.5-8.5$ & $\begin{array}{l}5.5- \\
7.3\end{array}$ & 7.4 & 7.3 & 6.9 & 7.4 \\
\hline TDS (mg/l) & 2000 & 3010 & 5080 & 1410 & 2740 & 810 \\
\hline TSS (mg/l) & 600 & 410 & 420 & 90 & 260 & 190 \\
\hline COD (mg/l) & 250 & 72 & 78 & 66 & 56 & 50 \\
\hline
\end{tabular}

\section{Interlinking of Lakes using GIS}

GIS is specifically useful for water quality management since its ability to capture, store, analyze, and view geographically referenced data. The growth of GIS applications for spatial data management and interpretation is increasing day by day. This study combined GIS analysis features with water quality parameters to link the lakes and the elevation of lakes. It is designed to process a wide variety of lake data and geo-referenced datasets, providing the required input data for water quality assessment methods and system planning. The related findings from the Case Study of the lake were then shown on GIS maps. The data is obtained from the toposheet to develop GIS with a scale of $1 \mathrm{~m}=5 \mathrm{~km}$. As the opensource software is nowadays used for the application, in this research, QGIS is used to extract the region unit data at the level of point, line, and area, Chennai Lakes. This study's main parameter is the length of linking and elevation between two lakes and water quality values. The toposheet extracted the various lakes in the study area, roads, railway lines, residential area, and other land uses. Figure 2 shows the study area's elevation map, which varies from $-10 \mathrm{~m}$ to $53 \mathrm{~m}$. Hence, linking the lakes required either cutting or filling of canals to the above slopes. Figure 3 shows the lakes with linking options with elevation superimposed. The elevation profile of the lakes and corresponding linking possible lakes are presented in Table 5, which is obtained from QGIS software. In Table 6, each linking lake and the maximum, minimum, starting points, and merging point and length of the canal are presented. These are the optimal length of the connecting the lakes, particularly length and slopes. Further, each lake's water quality is considered before connecting the lakes to maintain the same quality of water. The important point is small lakes will get filled early and drained the excess water to the main water supply lakes in the study area.

\section{Table 5 Elevation Profile Extracted from GIS to Interlink Lakes}


Linking Lakes

Puzhal to Ambattur

Puzhal Lake to Korattur Lake

Puzhal Lake to Retteri Lake

Ambattur to Korattur

Ayyapakkam to

Ambattur

Korathur to Retteri Lake

\section{Elevation and Distance (in M)}
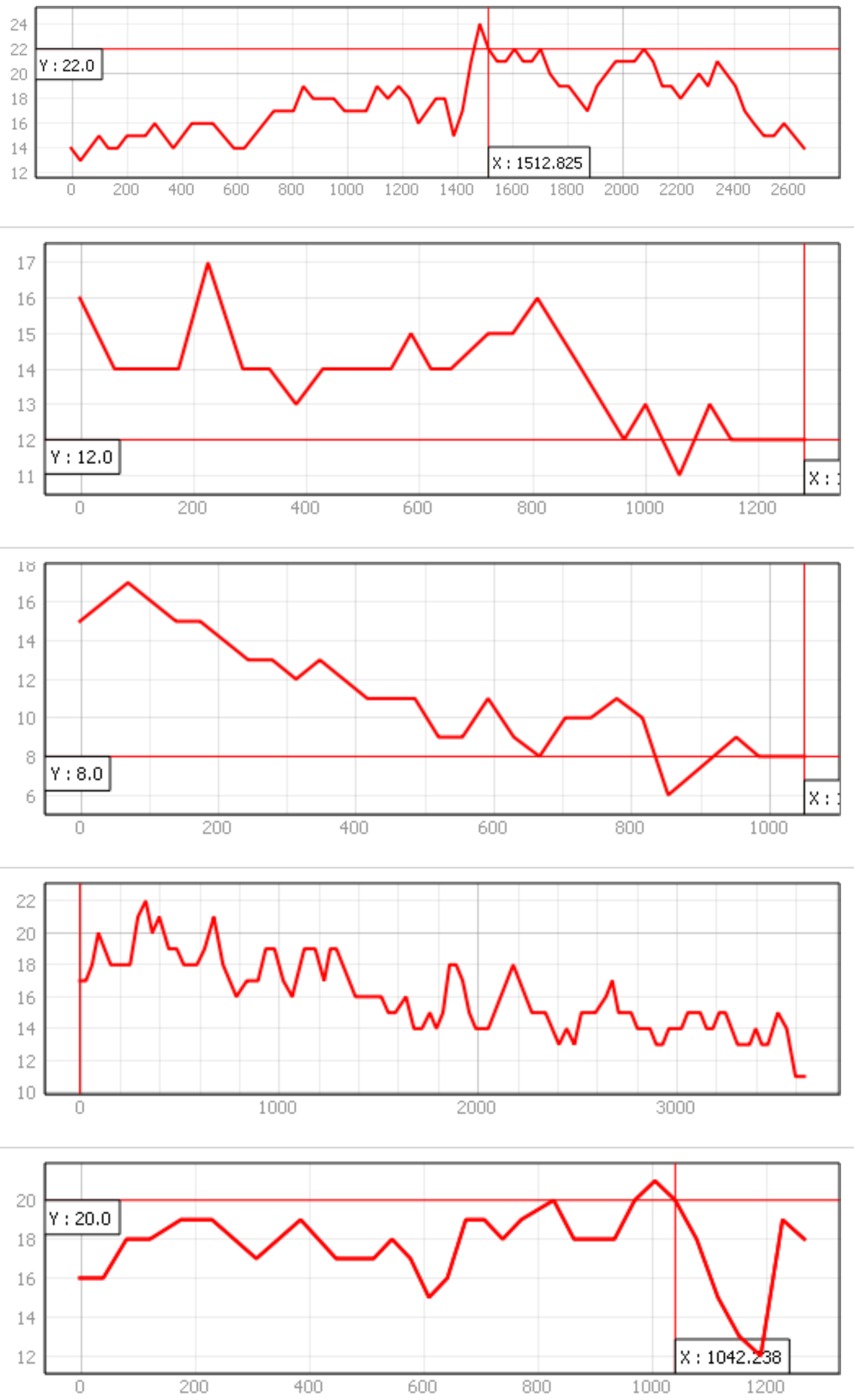


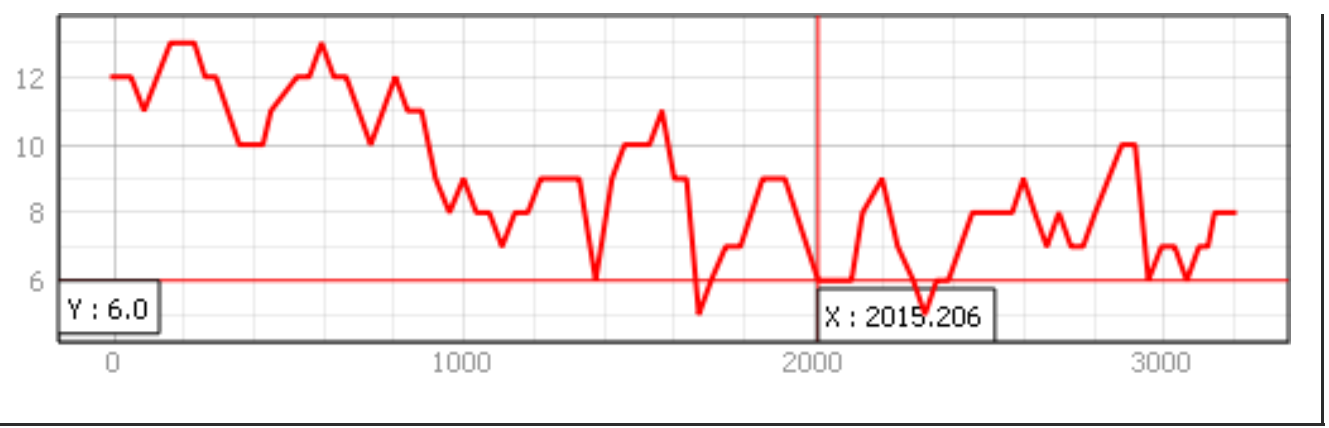

Table 6

Maximum and minimum Elevation and Length of the proposed Canal for interlinking

\begin{tabular}{|llllllll|}
\hline $\begin{array}{l}\text { Sl. } \\
\text { No }\end{array}$ & Lake & $\begin{array}{l}\text { Linking } \\
\text { Lake }\end{array}$ & $\begin{array}{l}\text { Starting } \\
\text { slope }(\mathrm{m})\end{array}$ & $\begin{array}{l}\text { Ending } \\
\text { Slope }(\mathrm{m})\end{array}$ & $\begin{array}{l}\text { Maximum } \\
\text { Slope }(\mathrm{m})\end{array}$ & $\begin{array}{l}\text { Minimum } \\
\text { Slope }(\mathrm{m})\end{array}$ & $\begin{array}{l}\text { Total } \\
\text { length } \\
(\mathbf{m})\end{array}$ \\
\hline 1 & Puzhal & Korattur & 16 & 12 & 17 & 11 & 1151 \\
\hline 2 & Puzhal & Retteri & 16 & 8 & 18 & 5 & 985 \\
\hline 3 & Puzhal & Ambattur & 14 & 14 & 25 & 11 & 2785 \\
\hline 4 & Ayapakkam & Ambattur & 16 & 12 & 21.91 & 11 & 1191 \\
\hline 5 & Ambattur & Koratture & 17 & 11 & 23 & 9.90 & 3643 \\
\hline 6 & Koratture & Retteri & 12 & 8 & 13.80 & 4 & 3203 \\
\hline
\end{tabular}

Excess water from each lake can be easily moved to other partially full lakes during rain seasons by interconnecting the lakes in Thiruvallur and Chennai districts. It is possible to reduce runoff waste in the research region thanks to these types of connectivity solutions. In addition, since geospatial technology is used to connect the lakes, an exact technique of determining the canal connection with the shortest and most efficient flood route may be applied. Once the link is created, the authorities may monitor and maintain the catchment areas of these lakes, which aids in the prevention of encroachment. Because the lakes are being connected by canals, the groundwater level can be maintained along the canal path and the canal due to the recharging of the water from these linking canals. During the summer seasons, it is noticed that the Puzhal lake alone supplies water to the study area; however, if these lakes are connected, water can be shared and delivered to the people for domestic use. The method of joining water with other lakes can be conducted without any additional investigation, thus this research is carried out with water quality examination in these lakes.

\section{Conclusions}

The canal's alignment is proposed based on hydrology, geology, land use views, out of which one is selected as the most suitable for interlinking of lakes. The alignment considers factors such as shortest distances between lakes, roads built-up areas, agricultural lands, etc. The canal's bed slope is not considered as the interlinking is done in between the overflow weir of the Korattur with that of the partially 
filled Puzhal lake. A field survey is conducted for arriving at the most reliable alignment and to achieve a minimum gradient. Water balance study and the overflow rate must be studied before determining the canal's size or culvert. Alignment 1 passes through agricultural lands, excluding the built-up areas (based on land use map). The actual length of the flow channel is $1.3 \mathrm{~km}$.

The alignment has a minimum length passing through agricultural land. It does not have a gradient for gravity flow. Presently agricultural lands have been converted to buildings. Alignment 2 connects Koratur upstream and Puzhal downstream and the length of the canal is about $3 \mathrm{~km}$, but it passes through the built-up areas or settlement areas. This alignment is between Puzhal downstream and Korattur upstream. Hence a gravity flow can be achieved. This alignment passes through the built-up area, adding up to the cost. It traces the longest path. This alignment follows a zigzag path passing through roads and has avoided the built-up areas. The length of the canal is $2 \mathrm{~km}$. A minimum gradient can be achieved for gravity flow. Advantages are that this alignment passes through the roadside; hence no demolition of the buildings is required, and gradient required for gravity flow can be achieved. The disadvantage is that the gradient achieved is minimum; hence it requires to have a large cross-section.

\section{Declarations}

\section{Ethical Approval}

Not Applicable

\section{Consent to Participate}

Yes

\section{Consent to Publish}

All the authors are consented to publish the work

\section{Authors Contributions}

P. P (Professor) contributed to problem identification, literature collection, and data analysis. B. A (Professor) is involved in problem identification, literature collection, data collection, and manuscript preparation. E. A. (Assistant Professor) contributed to data collection, data analysis, GIS development, and interpretation of results. K. S (Professor) contributed to data analysis, and manuscript preparation. C. H. (Assistant Professor) contributed to Data Collection, Fieldworks, and Surveying.

\section{Funding}

No Funding, Self-funding

\section{Competing Interests}


The data used in this research is available in the public database

\section{Availability of data and materials}

Not Applicable

\section{References}

1. Briscoe J. Water as an economic good: the idea and what it means in practice. World Congress of the International Commission on Irrigation and Drainage 1996:177-202.

2. Richard, H. Adams J. FCND Discussion Papers contain preliminary material and research results, and are circulated prior to a full peer review in order to stimulate discussion and critical comment. It is expected that most Discussion Papers will eventually be published in some. FCND Discussion Paper 1996.

3. Bank AD. Rehabilitation and management of tanks in india 2006:102.

4. Ahmed AA, Kit YW. MICIE: A Model for Identifying and Collecting Intrusion Evidences. 2016 12th International Conference on Signal-Image Technology \& Internet-Based Systems (SITIS), IEEE; 2016, p. 288-94. https://doi.org/10.1109/SITIS.2016.54.

5. Shah K V, Shah SD. Urban Stormwater Management Policy-Linking of Urban lakes for West Part of Vadodara city. International Journal of Technical Innovation in Modern Engineering \& Science 2015;45:2455-584.

6. British Water, SEPA, Environment Agency, NIEA. Code of Practice: Flows and Loads - 3 Sizing Criteria, Teratment Capactiy for Sewage Treatmet Systems. British Water Codes of Practice 2009:1-6.

7. Trout T, Bausch W, Buchleiter G. Does deficit irrigation give more crop per drop? Proceedings of the 22nd Annual Central Plains Irrigation Conference, Kearney, NE, February 24-25 2010:36-40.

8. Anand A. Linking Urban Lakes: Assessment of Water Quality and its Environmental Impacts 2014:73.

9. Mosse D. The Symbolic Making of a Common Property Resource: History, Ecology and Locality in a Tank-irrigated Landscape in South India. Development and Change 1997;28:467-504. https://doi.org/10.1111/1467-7660.00051.

10. Farrelly M, Brown R. Rethinking urban water management: Experimentation as a way forward? Global Environmental Change 2011;21:721-32. https://doi.org/10.1016/j.gloenvcha.2011.01.007.

11. Wood CH. Time, Cycles and Tempos in Social-ecological Research and Environmental Policy. Time \& Society 2008;17:261-82. https://doi.org/10.1177/0961463X08093425.

12. Cherekar MN, Pathak AP. Chemical assessment of Sambhar Soda Lake, a Ramsar site in India. Journal of Water Chemistry and Technology 2016;38:244-7. https://doi.org/10.3103/S1063455X1604010X.

13. Simonyan AE, Sargsyan AA, Hovhannisyan GG, Badalyan NS, Minasyan SH. Application of Crayfish Astacus Leptodactylus for the Analysis of Water Genotoxicity in the Lake Sevan Basin. Journal of Water Chemistry and Technology 2018;40:367-9. https://doi.org/10.3103/S1063455X18060097. 
14. Sivsankar V, Ramachandramoorthy T, Senthil Kumar M. Deterioration of coastal groundwater quality in Rameswaram Island of Ramanathapuram District, Southern India. Journal of Water Chemistry and Technology 2013;35:91-8. https://doi.org/10.3103/S1063455X13020082.

15. Dhanasekar K, Partheeban P. Assessment of physico-chemical characteristics of groundwater in Chennai. Nature Environment and Pollution Technology 2012;11.

16. Kowsalya R, Uma A, Meena S, Saravanabava K, Karrunakaran CM, Raman MD. Assessment of water quality and pollution of Porur double lake (Erettai Eri), Chennai. Journal of Industrial Pollution Control 2010;26:61-9.

17. Chennakrishnan C, Stephen A, Manju T, Raveen R. Water Quality Status of Three Vulnerable Freshwater Lakes of Suburban Chennai , India 2008;15:591-6.

18. Chapman D. Water Quality Assessments - A Guide to Use of Biota, Sediments and Water in Environmental Monitoring - Second Edition Edited by 1996.

19. Kuhn A, Britz W, Willy DK, van Oel P. Simulating the viability of water institutions under volatile rainfall conditions - The case of the Lake Naivasha Basin. Environmental Modelling and Software 2016;75:373-87. https://doi.org/10.1016/j.envsoft.2014.08.021.

20. Gopinath K, Seshachalam S, Neelavannan K, Anburaj V, Rachel M, Ravi S, et al. Quantification of microplastic in Red Hills Lake of Chennai city, Tamil Nadu, India. Environmental Science and Pollution Research 2020;27:33297-306. https://doi.org/10.1007/s11356-020-09622-2.

21. Hynds P, Regan S, Andrade L, Mooney S, O'Malley K, DiPelino S, et al. Muddy waters: Refining theway forward for the "sustainability science" of socio-hydrogeology. Water (Switzerland) 2018;10:1-16. https://doi.org/10.3390/w10091111.

22. Vasistha P, Ganguly R. Assessment of spatio-temporal variations in lake water body using indexing method. Environmental Science and Pollution Research 2020;27:41856-75. https://doi.org/10.1007/s11356-020-10109-3.

23. Watson-Leung T, Howell ET. Benthic invertebrate assemblage changes in an urban bay of Lake Ontario: 1990 to 2012. Journal of Great Lakes Research 2021;47:295-307. https://doi.org/10.1016/j.jglr.2020.12.008.

24. Hosseini N, Akomeah E, Davis J-M, Baulch H, Lindenschmidt K-E. Water quality modeling of a prairie river-lake system. Environmental Science and Pollution Research 2018;25:31190-204. https://doi.org/10.1007/s11356-018-3055-2.

25. Economopoulos AP. WHO_PEP_GETNET_93.1-A.pdf 1993.

\section{Figures}




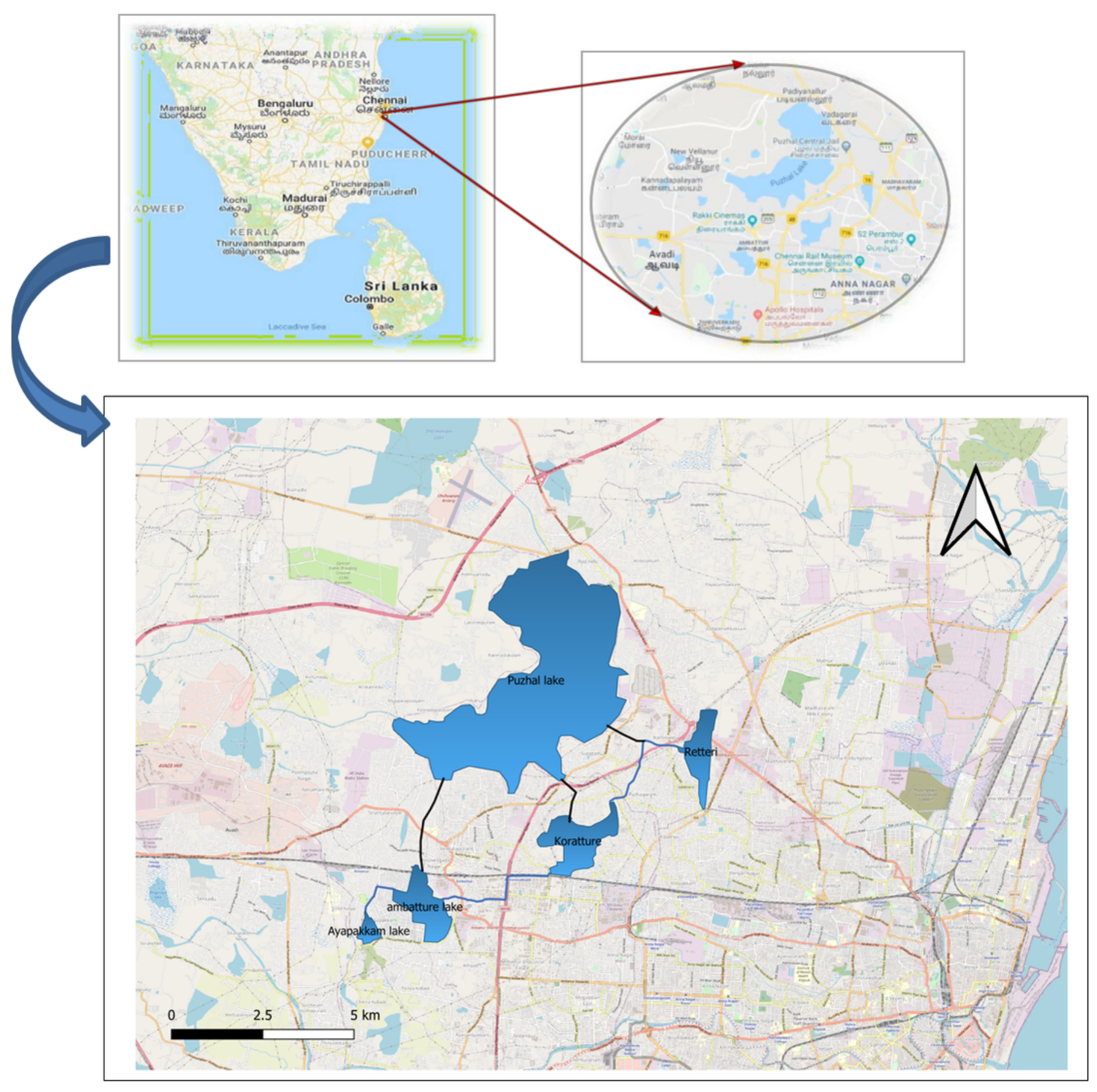

Figure 1

Study Area Map 


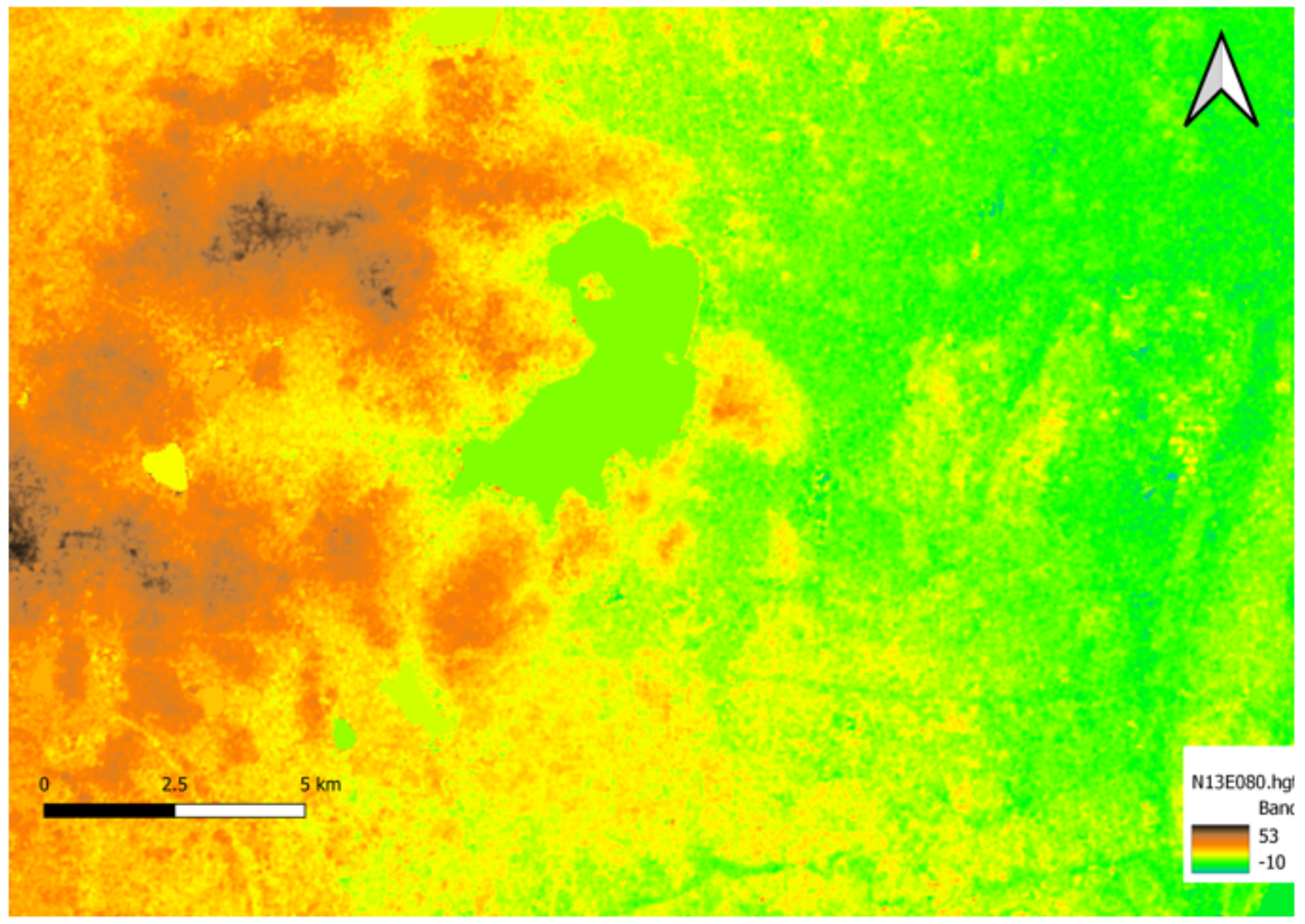

Figure 2

Elevation map of the Study Area 


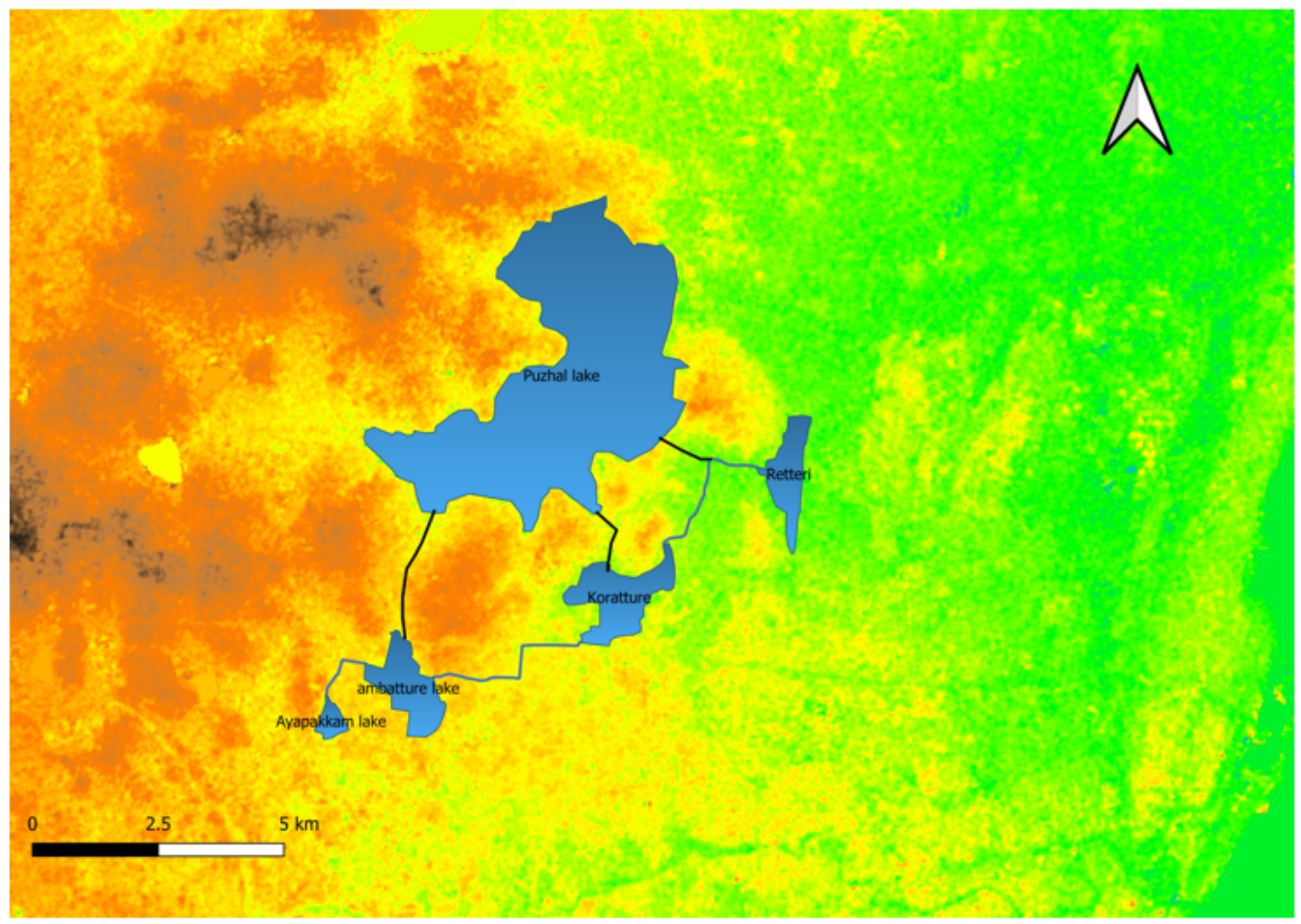

Figure 3

Lake Interlinking with Elevation Map 